\title{
LIGHT CONDITIONS IMPOSED BY CANOPY: ALLOMETRIC STRATEGIES OF AN UNDERSTOREY PALM (GEONOMA SCHOTTIANA MART.) IN ATLANTIC FOREST
}

\author{
Mendes $\mathrm{CN}^{1}$, Diniz ES ${ }^{2}$, Terra MCNS ${ }^{1}$, Jeannot $\mathrm{KK}^{3}$ \& Fontes $\mathrm{MAL}^{1, *}$ \\ ${ }^{1}$ Science Forest Department, Federal University of Lavras, Lavras, 3037 Brazil. \\ ${ }^{2}$ Department of Forest Engineering, Federal University of Viçosa, Vicosa, CEP 36570-900 Brazil \\ ${ }^{3}$ Official University of Rwenzori of Butembo, North Kivu, Democratic Republic of Congo, P.O. Box 11 \\ *fontes@ufla.br \\ Submitted September 2018; accepted February 2019
}

\begin{abstract}
One of the main factors driving high plant diversity in tropical forests is vertical stratification, which is determined by the ability of an individual to absorb light. The study aimed to evaluate the growth and reproduction strategies of the understorey palm species, Geonoma schottiana, based on allometric relationships and under different light conditions, in a semi-deciduous Atlantic forest. For this purpose, architectural parameters of 25 fruiting individuals were sampled, from which the number of fruits and infructescences were counted. The following parameters were also estimated: forest stratification, canopy (height and openness), crown variants (diameter, depth, openness and volume) and total height of the palm. A significant increment was found in the number of fruits with the increase in canopy opening and crown depth, while the number of infructescences increased with the total height of the palm. The proportion of variance explained by the number of infructescences was higher than that which was explained by the number of fruits. It was concluded that the fitness (i.e. production of fruits and infructescences) of $G$. schottiana is greatly influenced by the size of the individual (crown depth and total height) and canopy opening.
\end{abstract}

Keywords: Allometry, architectural model, resource allocation, forest stratification, trade-off, semi-deciduous Atlantic forest, shade tolerant species

\section{INTRODUCTION}

Tropical forests typically exhibit accentuated vertical stratification of vegetation due to the variety of strategies adopted by plants to maximise light absorption (Lieberman et al. 1995, Richards 1996, Ishii et al. 2004, Laurans et al. 2014). Such stratification is highlighted as one of the explanations of why tropical forest diversity is high, relative to other ecosystems with similar resource demands (Kohyama \& Takada 2009, Gravel et al. 2010). The higher the canopy level a plant occupies the less interference of light absorption there will be (Kohyama \& Takada 2009). Therefore, stratification creates a gradient of luminosity and resource restriction, which might limit the growth and reproduction of understorey plants (Roth 1984, Chazdon 1986a, Zavala et al. 2007).

Most of the neotropical palms (Arecaceae) have adaptations in physiology, architecture, phenology and morphology to tolerate shading, which permits their establishment in the forest understory (Chazdon 1986a, 1986b, de Granville 1992, Valladares \& Niinemets 2008). Furthermore, Arecaceae is considered important for forest structure as well as supplying food for fauna (Scariot 1999, Aguirre \& Dirzo 2008, Aguiar \& Tabarelli 2010). In spite of their importance, studies addressing the trade-off in palm growth and reproduction to deal with luminosity limitations are scarce (Kimura \& Simbolon 2002, Rodríguez-Buriticá et al. 2005). Research regarding palm allometry has mostly focused on the architectural behavior of their vegetative structures, photosynthetic responses and leaf demography (Chazdon 1985, Chazdon 1986a, Enright 1992, Takahashi \& Kohyama 1997, Gatti et al. 2011, Sampaio \& Scariot 2008, Sylvester \& Avalos 2013). Many of these studies either utilise models created for dicotyledonous plants or are specific to a single species (Malhi 
et al. 2004, Phillips et al. 2009). However, due to their monopodial growth and absence of secondary growth, palms constitute a group with very distinct strategies when compared with trees (Tomlinson 2006). In this study, it was aimed to elucidate the growth and reproduction strategies based on allometric relationships under different light conditions of the understory palm, Geonoma schottiana, within a semi-deciduous Atlantic forest in Brazil. The hypotheses state that 1) larger palms, either in height or crown diameter, will produce more infructescences and consequently more fruit, and 2) individuals with access to higher levels of luminosity will produce more fruit.

\section{MATERIALS AND METHODS}

\section{Study site}

The study was carried out in a semi-deciduous montane Atlantic forest at Parque Ecológico Quedas do Rio Bonito, located in the range of Bocaina Hill complex in the municipality of Lavras (21 $\left.{ }^{\circ} 19^{\prime} \mathrm{S}, 44^{\circ} 59^{\prime} \mathrm{W}\right)$. At this site the altitude ranges between 950 and 1200 meters. The climate, according to the Köppen System, is a transition between Cwb (dry winter oceanic climate) and Cwa (dry winter humid subtropical), that is, temperate with dry winters. The annual mean precipitation is $1,460 \mathrm{~mm}$ and the mean annual temperature is $20.4^{\circ} \mathrm{C}$.

\section{Study species}

The genus Geonoma (subfamily Arecoideae, tribe Geonomeae) encompasses around 50 species, widely distributed throughout America (Ostrorog \& Barbosa 2009). Geonoma schottiana, similar to other species from this genus, is an understorey palm associated with wet soils, with a range from the Atlantic forest domain to the Gallery forests of central Brazil (Chazdon 1991, Oliveira-Filho \& Ratter 1995). Its fruiting capacity throughout the year, plus the production of more than one infructescence at a time makes this palm a key species in many communities through its provision of food for fauna (Scariot 1999, Sampaio \& Scariot 2008). Similar to other species of this genus, such as G. undata and G. brevispatha, birds are the most common method by which the fruits of G. schottiana are dispersed (Wenny 2005, Ostrorog \& Barbosa 2009).

\section{Data collection}

Field work was conducted over a period of two weeks in May, during the dry season in southeast of Brazil. A total of 25 fruiting individuals, higher than two meters, were identified, from which the following data was collected: total height of the palm (from the base of the stem to the top of the youngest expanding leaf), crown depth (from the base of the crown to the top of the youngest expanding leaf), crown diameter (the largest and the smallest, visually defined using a measuring tape), and canopy height. From each individual palm, one infructescence with green fruits was randomly collected. Infructescences of green fruits were chosen since these were less likely to have lost fruits and would therefore more accurately represent the maximum yield of the palms. Each infructescence was immediately stored in an individual plastic bag to avoid loss of fruits during transportation to the Federal University of Lavras, for counting.

A spherical densiometer was used to estimate the percentage of canopy opening (Baudry et al. 2014). Measurements were taken immediately, surrounding the crown of each individual palm, which was then used to represent the quantity of light available to each individual. The densiometer was used to estimate the percentage of crown openness beneath each individual, close to the base of the stipe. This represents the fraction of luminosity that is not intercepted by the individual's crown. All measurements were taken by a single observer at a height of $130 \mathrm{~cm}$ from the ground.

The degree of forest stratification was estimated visually in the field by a single person, who assessed the degree of vertical stratification according to a scale of 4 categories, considering the layers of plant species composing different strata of the forest. Category 1 represented an environment with the lowest degree of stratification, with the forest consisting of just one layer of plant species. Category 2 comprised two to three layers, and category 3 , four layers. Category 4 was reserved for the highest degree of stratification of the forest, consisting of at least five layers.

To further investigate the relationship between crown parameters, luminosity and fruit production, the two crown diameters (larger and smaller) and the crown depth were used to 
calculate an additional predictor variable, crown volume. For this, first used were the two crown diameters to calculate the ellipse (A):

$$
\mathrm{A}=\pi \times \mathrm{a} \times \mathrm{b}
$$

where $a$ is the larger crown diameter and $b$ the smaller one. This was then multiplied by the crown depth to provide the crown volume.

Photos of the leaves in initial and mature ontogenetic stage, and also of an inflorescence and of an infructescence with green fruits, are shown in Appendix 1.

\section{Data analysis}

First, the correlation among the independent variables (canopy opening, canopy height, crown depth, crown openness, crown volume, crown diameter, stratification and total height of palm) were tested by applying Pearson correlation tests (r) and variance inflation factor (vif) in order to check for multicollinearity. For this, Pearson's coefficient was calculated using the R library Performance Analytics (Peterson and Carl 2014). For the Pearson tests the threshold $(<0.7)$ was considered, described by Dormann et al. (2013) as the cutoff. If the correlation among the predictors significantly exceeds this threshold (0.7), collinearity begins to severely distort model estimation and subsequent prediction (Dormann et al. 2013). The variance inflation factor was computed using the function vif of the package companion to applied regression (car) version 2.1-4 (Fox \& Weisberg 2011), considering vif $<5$ as the threshold (Kline 2011, Allison 1999, Zuur et al. 2010). Significant collinearity above the threshold of the Pearson tests $(r>0.70$, Appendix $2)$ and vif $(>10)$ was found between larger and smaller crown diameter and between crown volume and larger crown diameter. Thus, to avoid predictors with severe collinearity within a model, two separate global models were constructed: i) a model with larger crown diameter and ii) another model with crown volume replacing larger crown diameter. The smaller crown diameter was not included in either model. The linear relationship was also pre-tested among the target and predictor variables using local maximum (LM) models, with cumulative residual processes (cumres) function of the package goodness-of-fit (gof) 0.9.1, to perform Kolmogorov-Smirnov and Cramér-Von Mises $(\mathrm{CvM})$ tests, considering $\mathrm{p}<$
0.05 as the significance criteria (Lin et al. 2002, Holst 2014). These LM models contained the same complete set of predictors included in the two global models described below. It was found that all relationships among the dependent and independent variables were linear $(p>0.05)$, for both tests.

Following the above procedures, two global models (fruit model and infructescence model), including the dependent and independent variables, were constructed using generalised linear model (GLM). These global models were then submitted to selection following Akaike criterion (Second-Order Akaike Information Criterion) using the function dredge of the package MuMIn (Barton 2016). The first global model had the number of fruits as the target variable, and the second the number of infructescences. These two global models were tested using two arrays of predictors to avoid multicollinearity, since some of the variables were highly correlated (Appendix 2). The first array of predictors were crown openness, canopy opening, stratification, canopy height, total height of the palm, crown diameter and crown depth. The larger crown diameter was used and smaller crown diameter was rejected, as these two variables were highly correlated. The second array included predictors used in the first one, but replacing crown diameter with crown volume.

The first model, with the number of fruits as the dependent variable, was computed using Negative Binomial distribution of the package MASS, since both Poisson and Quasipoisson models showed overdispersion (Venables \& Ripley 2002, O’Hara \& Kotze 2010). In the second model, with the number of infructescences as the dependent variable, Poisson distribution was used, since there was neither under nor overdispersion in the models. The model with the lower value of AICc (Akaike value) and a delta value less than 2 was selected as the best model (Burnham \& Anderson 2002). In addition, it was taken into account the models with the second lowest values of AICc, and delta lower than two, by considering these models and the best ones as equally parsimonious (Burnham et al. 2011). The significance of the models with Negative Binomial and Poisson distribution was calculated by computing an analysis of deviance table (type II tests) with the function Anova from the package car (Fox \& Weisberg 2011, Appendix $3 \& 4$ ). This Anova works reliably for both types 
of models and is not hierarchical, allowing all predictors to have the same chance of being significantly related to the dependent variable. The (pseudo) R-squared based on Zhang's v were computed for these best models (Negative Binomial and Poisson) using the function rsq of the package rsq (Zhang 2017, 2018). The (pseudo) R-squared works as goodness-of-fit measure for Poisson models, which explains the proportion of variation in the dependent variable explained by the predictors included in the model (Heinzl \& Mittlboeck 2003).

\section{RESULTS}

The first global model submitted to Akaike criterion included the number of fruits as the dependent variable, and the second, the number of infructescences (Table 1). These models included larger crown diameter as an independent variable but not crown volume. The findings showed a significant increment in the number of fruits as the crown depth increased (Table 1, Figure 1a, Appendix 3). The number of fruits also increased significantly with canopy opening (Table 1 , Figure 1b, Appendix 3). The number of infructescences only showed a significant positive relationship with the total height of the palm (Table 1, Figure 1c, Table Appendix 3). That is, as the height of the palm increases, so does the number of infructescences. When crown volume was included as an independent variable (Table 2, Appendix 4), results indicated that it did not have a significant influence on the production of fruits and infructescences. However, the significant relationships of canopy opening and crown depth with number of fruits and total height with infructescences remained when crown volume was included in the models (Table 2, Appendix 4). All models with the number of infructescences as dependent variable presented higher proportion of variation explained (pseudo) R-squared than the models with number of fruits as dependent variables (Tables $1 \& 2$ ).

\section{DISCUSSION}

The observed relationship between fruit production and the increase of the percentage of canopy opening (Figure 1b) was expected, since light interception is essential for plant growth and reproduction (Chazdon 1986a, Freitas et al. 2016). Understorey species, such as G. schottiana, represent an example of plants prevailing in low light conditions, and despite their ability to thrive in this environment, the growth and reproductive success of this species remains

Table 1 The best models selected following the Akaike criterion regarding relationships of dependent variables (number of fruits and number of infructescences) with independent variables (crown openness, canopy openness, canopy height, stratification, total height, larger crown diameter and crown depth)

\begin{tabular}{lcccc}
\hline & Fruit-1 $^{\text {st }}$ & Fruit-2 $^{\text {nd }}$ & Infructescence-1 $^{\text {st }}$ & Infructescence-2 $^{\text {nd }}$ \\
\hline Intercept 1 & 5.23 & - & 0.66 & - \\
Intercept 2 & - & 5.54 & - & 1.56 \\
Crown openness & & & & \\
Canopy openness & 0.03 & 0.03 & & \\
Stratification & & & & \\
Canopy heigth & & -0.02 & 0.16 & \\
Total height & & & & -0.51 \\
Crown diameter & 0.75 & 0.78 & 0.37 & 0.51 \\
Crown depth & 0.12 & 0.15 & 2 & 3 \\
$\mathrm{R}^{2}$ & 4 & 5 & 96.6 & 97 \\
df & 357.3 & 349.2 & 0.02 & 0.4 \\
AICc & 0.01 & 1.98 & 0.14 & 0.12 \\
Delta & 0.27 & 0.67 & & \\
Weight & & & & \\
\hline
\end{tabular}

Infructescence $=$ number of infructescences, Fruit- $1^{\text {st }} \&-2^{\text {nd }}$ and Infructescence- $1^{\text {st }} \&-2^{\text {nd }}$ are, respectively, the two best models for each dependent variable; Intercept $1 \& 2$ regards to the intercepts in the two best models of each dependent variable; $\mathrm{R}^{2}=$ (pseudo)-squared based on Zhang's v, $\mathrm{df}=$ degrees of freedom, AICc = Akaike value 

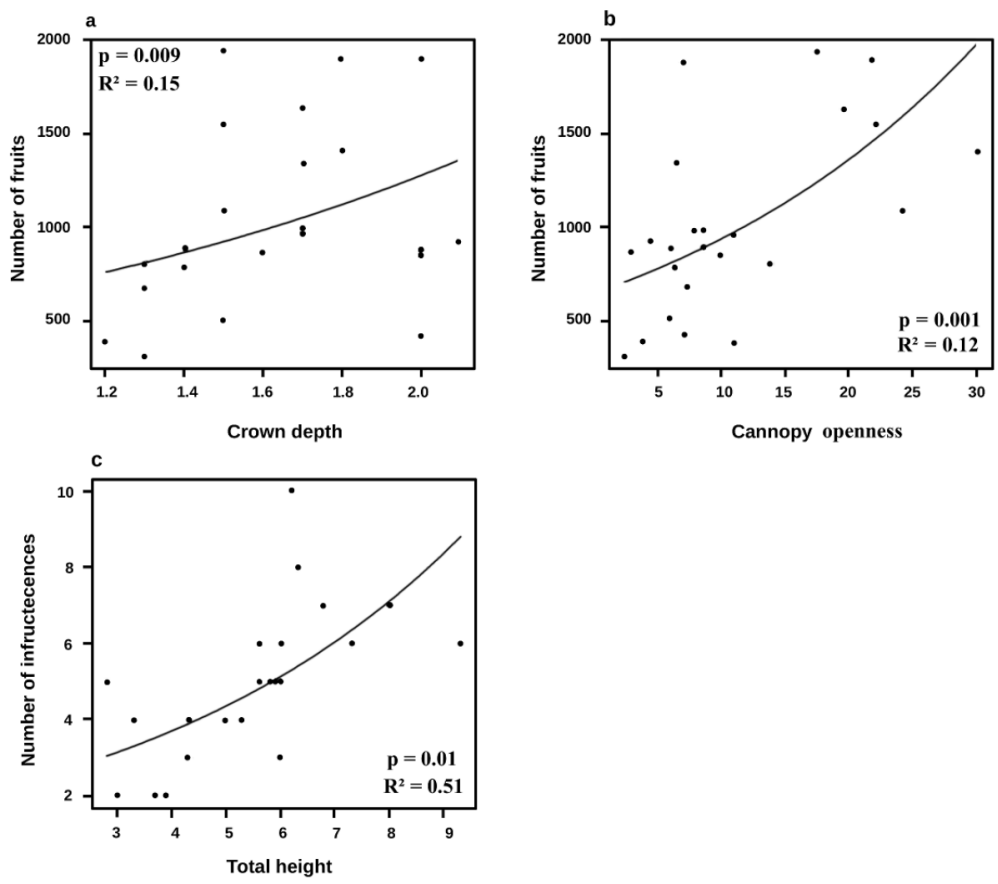

Figure 1 a) Relationship between number of fruits and crown depth, b) relationship between number of fruits and canopy openness and c) relationship between number of infructescences and total height of the palm

Table 2 The best models selected following the Akaike criterion regarding the relationships of the dependent variables (number of fruits and number of infructescences) with crown volume included among the predictors replacing crown diameter

\begin{tabular}{lcccc}
\hline & Fruit-1 $^{\text {st }}$ & Fruit-2 $^{\text {nd }}$ & Infructescence-1 $^{\text {st }}$ & Infructescence-2 $^{\text {nd }}$ \\
\hline Intercept 1 & 5.23 & - & 0.66 & - \\
Intercept 2 & - & 5.34 & - & 1.56 \\
Crown openness & & & & \\
Canopy openness & 0.03 & 0.03 & & \\
Stratification & & & 0.16 & \\
Canopy height & & & & 0.14 \\
Total height & 0.75 & 0.85 & & \\
Crown depth & & -0.006 & 0.37 & -0.51 \\
Crown volume & 0.12 & 0.14 & 2 & 0.41 \\
R $^{2}$ & 4 & 5 & 96.60 & 3 \\
df & 357.20 & 350.30 & 0.02 & 97.10 \\
AICc & 0.01 & 1.99 & 0.14 & 0.40 \\
Delta & 0.27 & 0.07 & & 0.11 \\
Weight & & & & \\
\hline
\end{tabular}

Infructescence $=$ number of infructescences; Fruit $-1^{\text {st }} \&-2^{\text {nd }}$ and Infructescence- $1^{\text {st }} \&-2^{\text {nd }}$ are, respectively, the two best models for each dependent variable; Intercept $1 \& 2$ regards to the intercepts in the two best models of each dependent variable; $\mathrm{R}^{2}=$ (pseudo)-squared based on Zhang's v, df = degrees of freedom, AICc $=$ Akaike value

heavily influenced by light availability (Chazdon \& Fetcher 1984, Chazdon 1991, Montgomery 2004, Valladares \& Niinemets 2008). The findings regarding the relationships between number of fruits and crown depth, and between the number of infructescences and total height (Figures 1a \& c, respectively) exemplify a well-known correlation between size and reproduction, where the larger the size of the individual, the greater the investment in reproductive structures 
(Piñero \& Sarukhán 1982, Enright 1992, Barot et al. 2005, Andrade et al. 2007, Bonser \& Aarssen 2008, Weiner et al. 2009, Sylvester \& Avalos 2013). Nevertheless, it is important to consider that increasing leaf production and, consequently, creating leaf overlap (represented by crown depth in our case) has the potential to introduce self-shading, limiting the benefit of increasing leaf production (Alvarez-Clare \& Avalos 2007). However, the entirely pinnate leaf of the individuals of Geonoma schottiana ameliorates this shading (Uhl et al. 2008).

The strategy regarding the increase in crown depth increasing fitness (increased production of infructescences and fruits) is in accordance with the architectural model of Corner fitted by Hallé et al. (1978). This model describes plants with only one stipe, without lateral ramification, which limits the optimisation of light absorption in the horizontal plane. Thus, it was expect to find larger crowns in sites with smaller canopy opening as a result of a horizontal strategy to make more efficient use of the available light (Fontes 1999). However, this study found no evidence of a significant relationship between larger crown diameter and the dependent variables (number of infructescences and fruits), likely because there was little variation in leaf length of our sampled individuals of Geonoma schottiana. Therefore, the results did not indicate a significant relationship between crown diameter and light availability, similar to the absence of correlation between total height of the plant and crown diameter, which are well-known explored relationships in various allometric studies (King 1996, 1990, Alves \& Santos 2002, Duque et al. 2017). This divergence in the fitting of allometric models to understorey palms is unsurprising since a relatively low number of articles specific to this subject have been published, thus emphasising the importance of this study. It also suggests that the allometry of palms is very different to that of trees since they have monopodial growth and no secondary growth (Schatz et al. 1985, Rich 1986, Rich et al. 1986, Tomlinson 1990, Alves et al. 2004, Tomlinson 2006, Goodman et al. 2013) .

The relationships presented in this study (Figures 1a, b, c) demonstrate strategies of the occupation of space and resource allocation which are underpinned by phenotypic differences, since individuals of the same species present different behaviors under different environmental conditions (e.g. distinct levels of stratification and light), either for vegetative growth or for reproduction (Thomas \& Bazzaz 1999, Svenning 1999, Souza \& Martins 2004, Weiner et al. 2009, Eiserhardt et al. 2011).

The study did not find any significant correlation between crown depth and canopy opening. This may be explained by the semideciduous nature of the forest. The variations in luminosity in the understorey are seasonal, occurring in the dry period, which has an average duration of six months. Individuals located under canopy species with perennial leaves, as opposed to deciduous or semideciduous, which are likely to experience lower levels of luminosity and thus develop deeper crowns. The relationship between crown depth and reproductive vigor (fitness) may be masked since the data was collected during the rainy season, a period in which the deciduous and semi-deciduous are in full leaf (Oliveira-Filho 2009). To further understand the mechanism of controlling the proportion of resources committed to reproduction versus vegetative growth, it is proposed that further data collection and analysis of the seasonal state (deciduous or perennial) of the surrounding vegetation is required. This will enable to

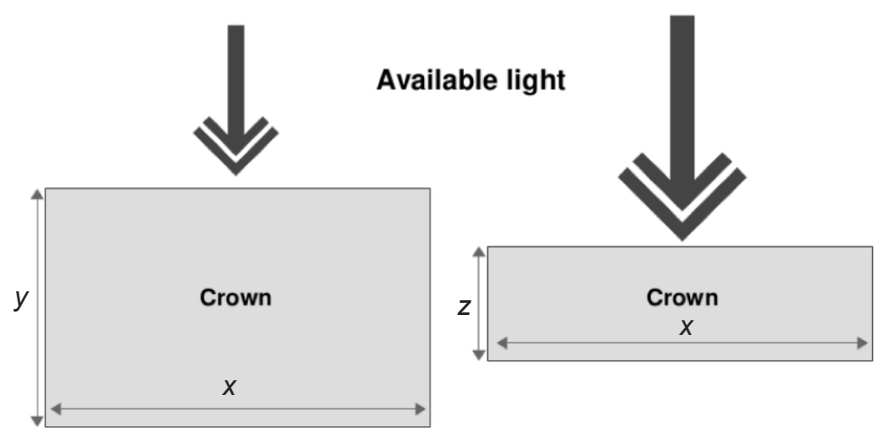

Figure 2 A diagram demonstrating crown behavior in Geonoma schottiana under different light conditions, where $\mathrm{x}$ represents the crown diameter and $\mathrm{y}$ and $\mathrm{z}$ are the distinct crown depths 
determine how seasonal variations in luminosity might affect reproductive vigor in understory palms.

This study is the first research on relationships between allometry and reproduction of $G$. schottiana in Atlantic semideciduous forest. The findings in this study expanded the knowledge regarding allometric relationships of palms. The findings concluded that the fitness (i.e. production of fruits and infructescences) of the understorey palm G. schottiana is greatly influenced by the size of the individual (crown depth and total height) and canopy opening. Nevertheless, further work is required to refine models of palm allometry, since the highly specialised growth traits of palms do not fit the well-established models used for dicotyledons. Therefore, the study underlines the importance of further research defining the allometric behaviour of palm trees, in order to better understand the mechanisms and strategies of growth and reproduction of palms, allowing to make inferences about their competitive capacity and their capacity to adapt to changing environments.

\section{ACKNOWLEDGEMENTS}

The authors would like to thank CAPES (Coordenação de Aperfeiçoamento de Pessoal de Nivel Superior) and FAPEMIG (Fundação de Amparo à Pesquisa do Estado de Minas Gerais) for granting scholarship, Parque Ecológico Quedas do Rio Bonito-Fundação Abraham Kasinski for allowing the study and Wheeldon E for the revision of the text.

\section{REFERENCES}

Aguiar AV \& Tabarelli M. 2010. Edge effects and seedling bank depletion: the role played by the early successional palm Attalea oleifera (Arecaceae) in the Atlantic Forest. Biotropica 42: 158-166.

Aguirre A \& Dirzo R. 2008. Effects of fragmentation on pollinator abundance and fruit set of an abundant understory palm in a Mexican tropical forest. Biodiversity and Conservation 141: 375-384.

Allison P. 1999. Multiple Regression: A Primer. Pine Forge Press, Thousand Oaks.

Alves LF, Martins FR \& Santos FA. 2004. Allometry of a neotropical palm, Euterpe edulis Mart. Acta Botanica Brasilica 18: 369-374.

Alves LF \& SAntos FA. 2002. Tree allometry and crown shape of four tree species in Atlantic rain forest, south-east Brazil. Journal of Tropical Ecology 18: 245-260.
Andrade PM, Santos FAM \& Martins FR. 2007. Size structure and fertility in an Eriocnema fulva Naudin (Melastomataceae) population in Southeastern Brazil. Brazilian Journal of Biology 67: 685-693.

Alvarez-Clare S \& Avalos G. 2007. Light interception efficiency of the understory palm Calyptrogyne ghiesbreghtiana under deep shade conditions. Ecotropica 13: 1-8.

Barot S, Mitja D, Miranda I, Meija GD \& Grimaldi M. 2005. Reproductive plasticity in an Amazonian palm. Evolutionary Ecology Research 7: 1051-1065.

Barton K. 2016. MuMIn: Multi-Model Inference. R package version 1.42.1. http://r-forge.r-roject.org/pro-jects/ mumin/.

Baudry O, Charmetant C, Collet C \& Ponette Q. 2014. Estimating light climate in forest with the convex densiometer: operator effect, geometry and relation to diffuse light. European Journal of Forest Research 133: 101-110.

BONSER SP \& AARSSEN LW. 2008. Interpreting reproductive allometry: individual strategies of allocation explain size-dependent reproduction in plant populations. Perspectives in Plant Ecology, Evolution and Systematics 11: 31-40.

Burnham KP \& Anderson DR. 2002. Model Selection and Multimodel Inference: A Practical Information Theoretic Approach. $2^{\text {nd }}$ edition. Springer, New York.

BURNHAM KP, ANDERSON DR \& HUYVAERT KP. 2011. AIC model selection and multimodel inference in behavioral ecology: some background, observations and comparisons. Behavioral Ecology and Sociobiology 65: 23-35.

Chazdon RL. 1985. Leaf display, canopy structure, and light interception of two understory palm species. American Journal of Botany 72: 1439-1502.

Chazdon RL. 1986a. Light variation and carbon gain in rain forest understory palms. Journal of Ecology 74: 995-1012.

Chazdon RL. 1986b. The costs of leaf support in understory palms: economy versus safety. The American Naturalist 127: 9-30.

Chazdon RL. 1991. Plant size and form in the understory palm genus Geonoma: are species variations on a theme? American Journal of Botany 78: 680-694.

Chazdon RL \& Fetcher N. 1984. Photosynthetic light environments in a lowland tropical rain forest in Costa Rica. Journal of Ecology 72: 553-564.

DE GRANVILle JJ. 1992. Life forms and growth strategies of Guianan palms as related to their ecology. Institut Français D'Études Andines 21: 533-548.

Dormann CF, Elith J, Bacher S et al. 2013. Collinearity: A review of methods to deal with it and a simulation study evaluating their performance. Ecography 36: 027-046.

Dugue A, Saldarriaga J, Meyer V \& Saatchi S. 2017. Structure and allometry in tropical forests of Chocó, Colombia. Forest Ecology and Management 405: 309-318.

Eiserhardt WL, SvenNing JC, KissLing WD \& BALSLEv H. 2011. Geographical ecology of the palms (Arecaceae): determinants of diversity and distributions across spatial scales. Annals of Botany 108: 1391-1416.

ENRIGHT NJ. 1992. Factors affecting reproductive behaviour in the New Zealand nikau palm, Rhopalostylis sapida Wendl. et Drude. New Zealand Journal of Botany 30: 69-80. 
Fontes MAL. 1999. Padrões alométricos em espécies arbóreas pioneiras tropicais. Scientia Forestalis 55: 79-87.

Fox J \& Weisberg S. 2011. An R Companion to Applied Regression. SAGE Publications Inc., Los Angeles.

Freitas C, Costa FR, Barbosa C \& Cintra R. 2016. Restriction limits and main drivers of fruit production in palm in central Amazonia. Acta Oecologica 77: 75-84.

Gatti MG, Campanello PI \& Goldstein G. 2011. Growth and leaf production in the tropical palm Euterpe edulis: light conditions versus developmental constraints. Flora - Morphology, Distribution, Functional Ecology of Plants 206: 742-748.

Goodman RC, Phillips OL, Torres DDC, Freitas L, Cortese ST, Monteagudo A \& Baker TR. 2013. Amazon palm biomass and allometry. Forest Ecology and Management 10: 994-104.

Gravel D, Canham CD, Beaudet M \& Messier C. 2010. Shade tolerance, canopy gaps and mechanisms of coexistence of forest trees. Oikos 119: 475-484.

Hallé F, Oldeman RAA \& Tomlinson PB. 1978. Tropical Trees and Forests: An Architectural Analysis. $1^{\text {st }}$ edition. Springer-Verlag, Berlin Heidelberg.

Heinzl H \& Mittlboeck M. 2003. Pseudo R-squared measures for Poisson regression models with overor underdispersion. Computational statistics and data analysis 44: 253-271.

HoLsT KK. 2014. Gof: Model-diagnostics based on cumulative residuals. $\mathrm{R}$ package version 0.9.1. https://CRAN.Rproject.org $/$ package $=$ gof.

IshiI H, TANABE S \& Hiura T. 2004. Exploring the relationships among canopy structure, stand productivity and biodiversity of temperate forest ecosystems. Forest Science 50: 342-355.

Kimura M \& Simbolon H. 2002. Allometry and life history of a forest understory palm Pinanga coronata (Arecaceae) on Mount Halimun, West Java. Ecological Research 17: 323-338.

KING DA. 1996. Allometry and life history of tropical trees. Journal of Tropical Ecology 12: 25-44.

KING DA. 1990. Allometry of saplings and understory trees of a Panamanian forest. Functional Ecology 4: 27-32.

KLINE RB. 2011. Principles and Practice of Structural Equation Modelling. $3^{\text {rd }}$ edition. The Guilford Press, New York.

Konyama T \& TAKada T. 2009. The stratification theory for plant coexistence promoted by one-sided competition. Journal of Ecology 97: 463-471.

Laurans M, Hérault B, Vieilledent G \& Vincent G. 2014. Vertical stratification reduces competition for light in dense tropical forests. Forest Ecology and Management 329: 79-88.

Lieberman M, Lieberman D, Peralta R \& Hartshorn GS. 1995. Canopy closure and the distribution of tropical forest tree species at La Selva, Costa Rica. Journal of Tropical Ecology 11: 161-177.

Lin DY, WeI LJ \& YING Z. 2002. Model-checking techniques based on cumulative residuals. Biometrics 58: 1-12.

Malhi Y, Baker TR, Phillips OL et al. 2004. The aboveground coarse wood productivity of 104 Neotropical forest plots. Global Change Biology 10: 563-591.

Montgomery RA. 2004. Effects of understory foliage on patterns of light attenuation near the forest floor. Biotropica 36: 33-39.
O'HARA RB \& Kotze DJ. 2010. Do not log-transform count data. Methods in Ecology and Evolution 1: 118-122.

Oliveira-Filho AT \& Ratter JA. 1995. A study of the origin of central Brazilian forests by the analysis of plant species distribution patterns. Edinburgh Journal of Botany 52: 141-194.

Oliveira-Filho AT. 2009. Classificação das fitofisionomias da América do Sul cisandina Tropical e Subtropical: Proposta de um novo sistema-prático e flexível-ou uma injeção a mais de caos? Rodriguésia 60: 237-258.

OSTROROG DRV \& BARBOSA AAA. 2009. Biologia reprodutiva de Geonoma brevispatha Barb. Rodr. (Arecaceae) em mata de galeria inundável em Uberlândia, MG, Brasil. Revista Brasileira de Botânica 32: 479-488.

Peterson BG \& Carl P. 2014. Performance Analytics: Econometric tools for performance and risk analysis. $\mathrm{R}$ package version 1.5.2. https://github.com/ braverock/PerformanceAnalytics

Phillips O, Higuchi N, Vieira S, Baker TR, Chao KJ \& Lewis SL. 2009. Changes in Amazonian forest biomass, dynamics, and composition, 1980-2002. Geophysical Monograph Series 186: 373-387.

Piñero D \& SARUKHÁN S. 1982. Reproductive behavior and its individual variability in a tropical palm, Astrocaryum mexicanum. Journal of Ecology 70: 461-472.

Rich PM. 1986. Mechanical architecture of arborescent rain forest palms. Principles 30: 117-131.

Rich PM, Helenurm K, Kearns D, Morse SR, Palmer MW \& SHORT L. 1986. Height and stem diameter relationships for dicotyledonous trees and arborescent palms of Costa Rican tropical wet forest. Bulletin of the Torrey Botanical Club 113: 241-246.

Richards PW. 1996. The Tropical Rain Forest: An Ecological Study. $2^{\text {nd }}$ edition. Cambridge University Press, Cambridge.

Rodríguez-Buriticá S, Orjuela MA \& Galeano G. 2005. Demography and life history of Geonoma orbignyana: an understory palm used as foliage in Colombia. Forest Ecology and Management 211: 329-340.

Rотн I. 1984. Stratification of Tropical Forest as Seen in Leaf Structure. Springer, Dordrecht.

SAMPAIO MB \& SCARIOT A. 2008. Growth and reproduction of the understory palm Geonoma schottiana Mart. in the gallery forest in Central Brazil. Brazilian Journal of Botany 31: 433-442.

SCARiot A. 1999. Forest fragmentation effects on palm diversity in central Amazonia. Journal of Ecology 87: 66-76.

Schatz GE, Williamson GB, Cogswell CM \& Stam AC. 1985. Stilt roots and growth of arboreal palms. Biotropica 17: 206-209.

SOUZA AF \& MARTINS FR. (2004). Microsite specialization and spatial distribution of Geonoma brevispatha, a clonal palm in south-eastern Brazil. Ecological Research 19: 521-532.

SvenNing JC. 1999. Microhabitat specialization in a species rich palm community in Amazonian Ecuador. Journal of Ecology 87: 55-65.

Sylvester O \& Avalos G. 2013. Influence of light conditions on the allometry and growth of the understory palm Geonoma undata subsp. edulis (Arecaceae) of neotropical cloud forests. American Journal of Botany 100: 2357-2363. 
TAKAHASHI K \& KoHYAma T. 1997. Crown architecture of two understory palm species of the genus Licuala in a Tropical Rain Forest. Plant Species Biology 12: 35-41.

Thomas SC \& Bazzaz FA. 1999. Asymptotic height as a predictor of photosynthetic characteristics in Malaysian rain forest trees. Ecology 80: 1607-1622.

Tomlinson PB. 2006. The uniqueness of palms. Botanical Journal of the Linnean Society 151: 5-14.

Tomlinson PB. 1990. The Structural Biology of Palms. $1^{\text {st }}$ edition. Clarendon Press, Oxford.

Uhl NW, Dransfield J, Asmussen CB, Baker WJ, Harley M \& LewIS C. 2008. Genera Palmarum: The Evolution and Classification of Palms. International Palm Society, Austin.

Valladares F \& Nirnemets U. 2008. Shade tolerance, a key plant feature of complex nature and consequences. Annual Review of Ecology, Evolution and Systematics 39: 237-257.

Venables WN \& Ripley BD. 2002. Modern Applied Statistics with $S .4^{\text {th }}$ edition. Springer, New York.
Weiner J, Campbell LG, Pino J \& Echarte L. 2009. The allometry of reproduction within plant populations. Journal of Ecology 97: 1220-1233.

Wenny DG. 2005. Post-dispersal seed fate of some cloud forest tree species in Costa Rica. Pp 351-361 in Forget PM et al. (eds.) Seed Fate. CABI Publishing, Wallingford.

Zavala MA, Angulo O, De la Parra R \& Lopez-Mareos JC. 2007. An analytical model of stand dynamics as a function of tree growth, mortality and recruitment: The shade tolerance-stand structure hypothesis revisited. Journal of Theoretical Biology 244: 440-450.

ZHANG D. 2017. A coefficient of determination for Generalized Linear Models. The American Statistician 71:310-316.

Zhang D. 2018. rsq: R-Squared and Related Measures. R package version 1.1. https://CRAN.R-project.org/ package $=$ rsq

Zuur AF, IENo EN \& ELPHICK CS. 2010. A protocol for data exploration to avoid common statistical problems. Methods in Ecology and Evolution 1: 3-14. 


\section{Appendixes}

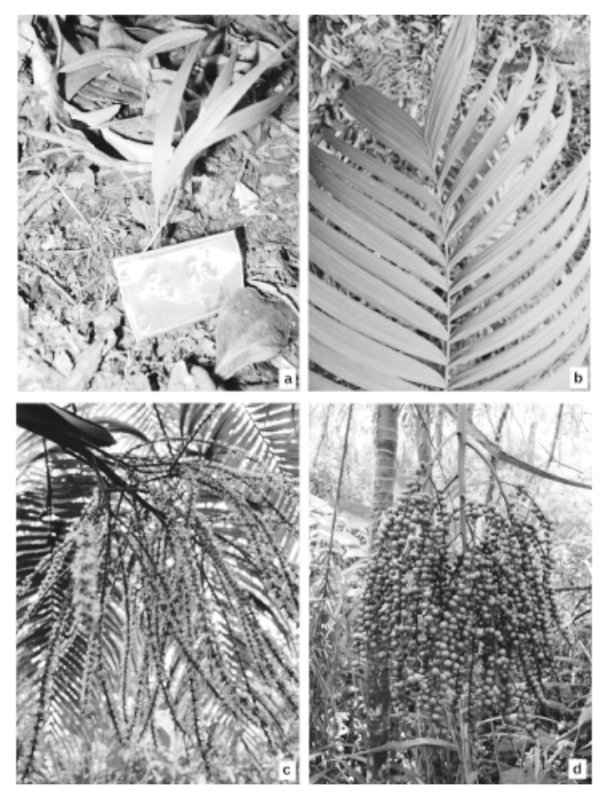

Appendix 1 Photos of a Geonoma schottiana seedling (a), a mature leaf frond (b), an inflorescence (c) and an infructescence with green fruits $(d)$

Appendix 2 Pearson correlation coefficients ( $r$ ) of the independent variables used in the final models (number of fruits and infructescences)

\begin{tabular}{lccccccccc}
\hline & $\begin{array}{c}\text { Crown } \\
\text { diameter } \\
\mathrm{L}\end{array}$ & $\begin{array}{c}\text { Crown } \\
\text { diameter } \\
\mathrm{S}\end{array}$ & $\begin{array}{c}\text { Crown } \\
\text { depth }\end{array}$ & $\begin{array}{c}\text { Total } \\
\text { height }\end{array}$ & $\begin{array}{c}\text { Canopy } \\
\text { height }\end{array}$ & Stratification & $\begin{array}{c}\text { Crown } \\
\text { openness }\end{array}$ & $\begin{array}{c}\text { Canopy } \\
\text { openness }\end{array}$ & $\begin{array}{c}\text { Crown } \\
\text { volume }\end{array}$ \\
\hline Crown diameter L & 1 & 0.74 & 0.05 & 0.06 & 0.05 & -0.13 & 0.16 & 0.10 & 0.77 \\
Crown diameter S & 0.74 & 1 & 0.01 & 0.03 & 0.04 & -0.3 & -0.06 & 0.04 & 0.66 \\
Crown depth & 0.05 & 0.01 & 1 & -0.24 & -0.09 & -0.2 & -0.06 & 0.16 & 0.39 \\
Total height & 0.06 & 0.03 & -0.24 & 1 & -0.21 & -0.04 & 0.34 & -0.05 & -0.24 \\
Canopy height & 0.05 & 0.04 & -0.09 & -0.21 & 1 & -0.04 & -0.05 & -0.28 & 0.25 \\
Stratification & -0.13 & -0.3 & -0.2 & -0.04 & -0.04 & 1 & 0.02 & 0.16 & -0.19 \\
Crown openness & 0.16 & -0.06 & -0.06 & 0.34 & -0.05 & 0.02 & 1 & 0.56 & 0.13 \\
Canopy openness & 0.10 & 0.04 & 0.16 & -0.05 & -0.28 & 0.16 & 0.56 & 1 & 0.05 \\
Crown volume & 0.77 & 0.66 & 0.39 & -0.24 & 0.25 & -0.19 & 0.13 & 0.05 & 1 \\
\hline
\end{tabular}

Crown diam $\mathrm{L}$ = larger crown diameter, Crown diam $\mathrm{S}$ = smaller crown diameter, Total height = total height of the palm 
Appendix 3 The significance of the relationships among the variables of the final models in table 1 of the main text computed by the function Anova of the package companion to applied regression (car)

\begin{tabular}{clcc}
\hline & & LR-Chisq & Pr ( > Chisq) \\
\hline & ${ }^{1}$ Canopy openness & 12.56 & 0.0003 \\
& ${ }^{1}$ Crown depth & 6.17 & 0.0010 \\
Fruit model & ${ }^{2}$ Canopy openness & 13.36 & 0.0010 \\
& ${ }^{2}$ Crown depth & 6.75 & 0.0090 \\
& ${ }^{2}$ Canopy height & 0.64 & 0.4210 \\
Infructescence & ${ }^{1}$ Total height & 8.07 & 0.0040 \\
model & ${ }^{2}$ Total height & 5.88 & 0.0110 \\
& ${ }^{2}$ Crown Depth & 2.22 & 0.1350 \\
\hline
\end{tabular}

${ }^{1} \&{ }^{2}$ indicate the two best models following Akaike Criterion (lower AICc and delta $<2$ ); LR = likelihood ratio, $\mathrm{Pr}=$ probability, Chisq = Chi-square

Appendix 4 The significance of the relationships among the variables of the final models in table 2 of the main text computed by the function Anova of the package companion to applied regression (car)

\begin{tabular}{clcc}
\hline & & LR-Chisq & $\operatorname{Pr}(>$ Chisq) \\
\hline & ${ }^{1}$ Canopy openness & 12.56 & 0.0003 \\
& ${ }^{1}$ Crown depth & 6.17 & 0.0010 \\
Fruit model & ${ }^{2}$ Canopy openness & 13.36 & 0.0002 \\
& ${ }^{2}$ Crown depth & 7.06 & 0.0071 \\
& ${ }^{2}$ Crown volume & 0.73 & 0.3910 \\
& ${ }^{1}$ Total height & 8.07 & 0.0040 \\
Infructescence model & ${ }^{2}$ Total height & 5.88 & 0.0100 \\
& ${ }^{2}$ Crown Depth & 2.22 & 0.1351 \\
\hline
\end{tabular}

${ }^{1} \&{ }^{2}$ indicate the two best models following Akaike Criterion (lower AICc and delta $<2$ ); $\mathrm{LR}=$ likelihood ratio, $\mathrm{Pr}=$ probability, Chisq $=$ Chi-square 